\title{
Abutment misfit in implant-supported prostheses manufactured by casting technique: An integrative
}

\author{
Lorena M. S. Pereira ${ }^{1}$, Mariane B. Sordi ${ }^{2}$, Ricardo S. Magini ${ }^{2}$, Antônio R. Calazans Duarte ${ }^{1}$, \\ Júlio C. M. Souza ${ }^{2,3}$
}

Correspondence: Dr. Júlio César Matias de Souza

Email: julio.c.m.souza@ufsc.br

\begin{abstract}
'Department of Dentistry, Federal University of Rio Grande do Norte (UFRN), Natal/RN, 59060-000, Brazil, ${ }^{2}$ Center for Research on Dental Implants (CEPID), Post-graduate Program in Dentistry, School of Dentistry (ODT), Universidade Federal de Santa Catarina (UFSC), Florianópolis/SC, 88040-900, Brazil, ${ }^{3}$ Center for MicroElectroMechanical Systems (CMEMS UMINHO), University of Minho, Portugal
\end{abstract}

\section{ABSTRACT}

The aim of this study was to perform an integrative review of the literature on the clinically usual prosthesis-abutment misfit over implant-supported structures manufactured by conventional casting technique. The present integrative review used the PRISMA methodology. A bibliographical search was conducted on the following electronic databases: MEDLINE/PubMed (National Library of Medicine), Scopus (Elsevier), ScienceDirect (Elsevier), Web of Science (Thomson Reuters Scientific), Latin American and Caribbean Center on Health Sciences Information (BIREME), and Virtual Health Library (BVS). A total of 11 relevant studies were selected for qualitative analysis. The prosthetic-abutment vertical misfit considered clinically usual ranged from 50 to $160 \mu \mathrm{m}$. The vertical misfit depends on several steps during technical manufacturing techniques, which includes the materials and technical procedures. Lower values in misfit are recorded when precious metal or titanium alloys are utilized. Although a vertical misfit mean value of $100 \mu \mathrm{m}$ has been considered clinically usual, most of the previous studies included in this revision showed lower mean values.

Key words: Dental crown, fixed prostheses, implant-supported prostheses, marginal misfit.

\section{INTRODUCTION}

Implant- supported prostheses are frequently used for oral rehabilitation and therefore osseointegrated dental implants do overcome many of the limitations found in conventional fixed and removable prostheses. ${ }^{[1-4]}$ Several factors must be considered to improve the long-term performance of implant-supported prostheses such as the distribution of stresses through the structural materials to the

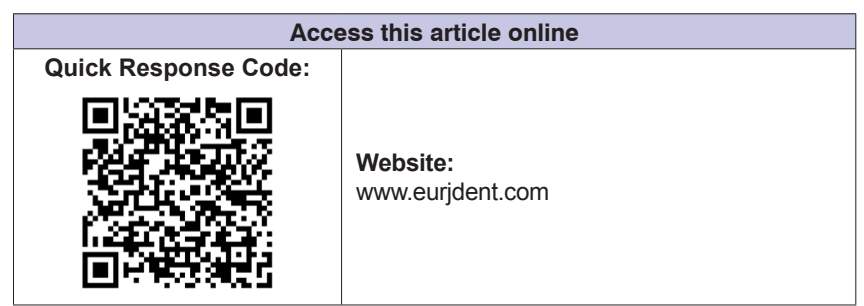

alveolar bone, the fitting of the connections, as well as the properties of the materials. ${ }^{[5-9]}$

On implant-supported prostheses, microgaps have been detected between abutment and implant contacting surfaces as well as between prosthetic structures and abutment. Such microgaps vary

This is an open access article distributed under the terms of the Creative Commons Attribution-NonCommercial-ShareAlike 3.0 License, which allows others to remix, tweak, and build upon the work non-commercially, as long as the author is credited and the new creations are licensed under the identical terms.

For reprints contact: reprints@medknow.com

How to cite this article: Pereira LM, Sordi MB, Magini RS, Calazans Duarte AR, M. Souza JC. Abutment misfit in implant-supported prostheses manufactured by casting technique: An integrative review. Eur J Dent 2017;11:553-8.

DOI: 10.4103/ejd.ejd_162_17 
depending on the processing of the prosthetic and implant structures, and therefore it can affect the mechanical performance of the prosthesis. ${ }^{[6-9]}$ Several studies have shown that a certain degree of inaccuracy is inevitable even with the current manufacturing processes such as computer-aided design-computer-aided manufacturing (CAD-CAM). [6-12] As a result, the penetration of oral fluids (e.g. glycoproteins and acidic substances) and biofilms could cause the decrease of friction between contacting surfaces and induce corrosion by the presence of bacterial metabolites. ${ }^{[1,6,7,13,14]}$

Implant-supported prostheses produced by conventional casting technique show technical complications caused by misfit between the prosthetic structure and the abutment. ${ }^{[3-8]}$ The misfit in implant connections can result in intense oblique loads and concentration of stresses at prosthetic and implant structures. ${ }^{[1,2,6,7,12,15]}$ That can induce loosening of mechanical integrity of abutment screw, fracture of ceramic prosthetic materials, and bone resorption. ${ }^{[1-12,15-20]}$ The selection of materials and design of implant-abutment-prosthesis assemblies is crucial to avoid mechanical issues such as fractures and overloads. ${ }^{[4-12]}$

The finite element method (FEM) is a tool that evaluates the distribution of stresses through structural materials by varying occlusal loading, design, and materials' properties. ${ }^{[21-23]}$ This method is performed to indicate biomechanical aspects of materials and human tissues that cannot be measured in vivo, ${ }^{[24]}$ allowing to evaluate the effect of several factors before laboratorial or animal studies. ${ }^{[21,22]}$ The magnitude of stresses transferred to the surrounding bone plays a key role in the long-term success of dental implants. Some factors that influence the load transfer from implant to bone are loading modality, bone-implant interface, length and diameter of the implants, shape and characteristics of the implant surface, type of prosthesis, and quantity and quality of the surrounding bone. ${ }^{[23,24]}$ The three-dimensional geometry of the jaw is important for planning the positioning, number, diameter, and length of dental implants. Virtual models can help the clinician in choosing a correct design for a prosthetic rehabilitation considering stress distribution from occlusal loading. ${ }^{[23,25,26]}$

The marginal abutment-prosthetic misfit is still an issue in implant and restorative dentistry once the complete connection sealing or cold welding does not occur. Within the issues related to vertical misfit, it is clear the need to achieve a minimum misfit in implant-supported prostheses. Thus, the present study aims to perform an integrative review of the scientific literature on the clinically usual prosthetic-abutment misfit over implant-supported rehabilitation manufactured by conventional casting techniques.

\section{METHODOLOGY}

The study followed the methodology proposed by PRISMA (2009) ${ }^{[27]}$ to perform systematic reviews. PRISMA methodology allows to conduct a wide variety of systematic reviews, ensuring reproducibility and traceability. A bibliographical search was conducted on the following electronic databases: MEDLINE/PubMed (through National Library of Medicine), Scopus (Elsevier), ScienceDirect (Elsevier), Web of Science (Thomson Reuters Scientific), Latin American and Caribbean Center on Health Sciences Information (BIREME), and Virtual Health Library (BVS). The following search terms were used: (tw: ["discrepancy" or "variance" or "misfit" or "discrepancies" or "discrepância" or "vertical"]) AND (tw: ["Implante" or "implant" or "implant-supported"]) AND (tw: ["Protético" or "prótese" or "próteses" or "ponte" or "coroa" or "crowns" or "frameworks"]). Laboratory studies with a minimum sample of two abutments were included, in which results were showed in for vertical misfit in micrometer obtained by optical or scanning electron microscopy. Articles from 2005 to 2015 were included. There were no language restrictions. Casecontrol studies, animal studies, letters, book chapters, reviews, and articles that did not comply with the requirements proposed were discarded. The evaluation of the potentially relevant articles by review of the title and abstract was completed independently by two of the authors. Selected articles were individually read and analyzed considering the purpose of this study. The review article variables considered for this review were authors' names, journal, publication year, marginal misfit on dental-supported fixed prostheses, implant-abutment misfit, or studies evaluating crowns that were not manufactured by the lost-wax technique such as scanners or CAD-CAM technologies.

\section{RESULTS AND DISCUSSION}

The flowchart of the search strategy is shown in Figure 1, and the selected articles within content details are listed in Table 1 . A total of 11 studies were identified for qualitative analysis. 


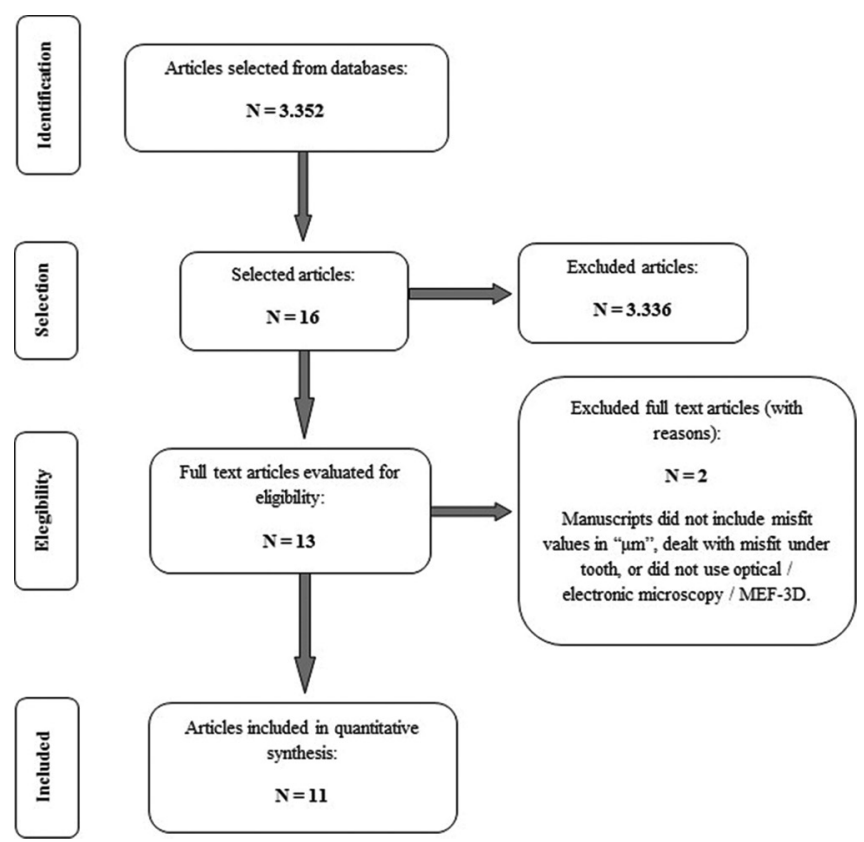

Figure 1: Flowchart of the search strategy

The largest vertical misfit considered as clinically usual in the sample analyzed was at 150-160 $\mu \mathrm{m} \cdot{ }^{[28-31]}$ Still, Bayramoğlu et al. ${ }^{[32]}$ reported values of up to $120 \mu \mathrm{m}$ and Barros et al. ${ }^{[5]}$ considered misfit values at $100 \mu \mathrm{m}$. The lowest values reported as clinically usual were at $70^{[33]}$ and $50 \mu \mathrm{m} \cdot{ }^{[34]}$ Oyagüe et al. ${ }^{[35]}$ do not discuss an acceptable range for vertical misfit.

There was a difference between the values considered acceptable and the values found by the authors as shown in Figure 2, although only two articles showed higher misfit values in the experiment than those expected. ${ }^{[5,34]}$ The study of Gomes ${ }^{[20]}$ was not included since it was a computational simulation of marginal discrepancy.

The lost-wax casting technique is still one of the most used procedures in manufacturing prosthetic crowns although poorer marginal adaptation has been recorded when compared to CAD/CAM systems. Barros et al. ${ }^{[5]}$ found discrepancy mean values of $108.63 \mu \mathrm{m}$ for cast bars and $9.65 \mu \mathrm{m}$ for the milled bar. All selected articles in the present study found that the misfit mean values regarding CAD/CAM technique were always lower when compared to those for casting. ${ }^{[30-32]}$

Marginal misfit is one of the factors to be analyzed for clinical success, always seeking the lowest values depending on the materials, casting techniques, cementation, torque, etc. The lowest marginal misfit was found for lost-wax method, but this result was not statistically significant when compared to burn-up

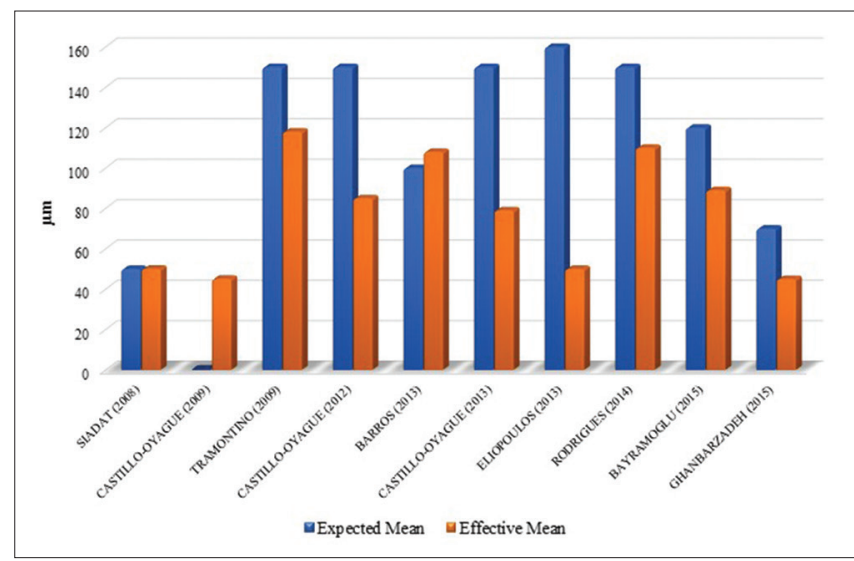

Figure 2: Vertical misfit expected mean (or clinically accepted) and effective mean found in each selected study

and impression cap. ${ }^{[34]}$ Regarding the comparison among modified caps, calcinable capsule, and the non-use of caps, Eliopoulos et al. ${ }^{[28]}$ reported more favorable results and reduced precision for vertical discrepancy when modified prefabricated plastic components were used.

Several alloys are used to produce the prosthetic crowns, and it is necessary to evaluate the cost effective. Precious metal alloys have better properties but higher costs. NiCr-based alloys are cheaper and have properties considered acceptable. ${ }^{[28]}$ Oyagüe et al. ${ }^{[35]}$ showed a significant difference when comparing alloys of CoCr-based, titanium, and AuPd-based. CoCr-based alloy revealed higher vertical misfit values, whereas Titanium and AuPd-based alloys were similar. Although a significant difference has been found among the alloys, all values are considered acceptable.

The cements utilized may also influence misfit of prosthesis-abutment and microleakage of oral fluids and biofilm. Previous studies performed ${ }^{[30,31]}$ have shown better results regarding marginal sealing for resinous glass ionomer $(\sim 68 \mu \mathrm{m})$ and urethane-based cements $(\sim 67 \mu \mathrm{m})$ than those recorded on dual-core resin cements $(95 \mu \mathrm{m})$. However, dual-core resin cements have better stability regarding microleakage since it is slightly soluble. Despite these results, there was no statistically difference among them.

For screw-retained implant-supported prostheses, it is hypothesized that the marginal gap contributes to a poor distribution of stresses. The study of Gomes ${ }^{[20]}$ simulated marginal and angular misfit, and the results showed that each discrepancy contributes to overloading at a specific region of the implant. Unilateral vertical misfit damages the infrastructure and total vertical misfit negatively affects the implant 
Pereira, et al.: Abutment misfit in implant-supported prostheses

\begin{tabular}{|c|c|c|c|c|c|c|}
\hline Authors & Sample size & $\begin{array}{c}\text { Acceptable } \\
\text { marginal misfit }(\mu \mathrm{m})\end{array}$ & Location & $\begin{array}{l}\text { Evaluation } \\
\text { methods }\end{array}$ & Data analyses & Year \\
\hline Siadat et al. & 24 crowns & 50.1 & - & SEM & $\begin{array}{l}\text { Evaluation of vertical and } \\
\text { horizontal misfit in cast } \\
\text { copings for single crowns }\end{array}$ & 2008 \\
\hline Castillo-Oyague et al. & $\begin{array}{l}30 \text { structures for } \\
\text { 3-elements fixed } \\
\text { prostheses }\end{array}$ & $44.87-45.42$ & $\begin{array}{l}\text { Premolars } \\
\text { to first } \\
\text { molars }\end{array}$ & SEM & $\begin{array}{l}\text { Comparison of the influence } \\
\text { of different alloys and } \\
\text { the associated investing } \\
\text { and casting techniques } \\
\text { on the marginal misfit of } \\
\text { fixed structures luted onto } \\
\text { prefabricated abutments }\end{array}$ & 2009 \\
\hline Tramontino et al. & 10 models & $30-150($ mean 118.07) & $\begin{array}{l}\text { Mandibular } \\
\text { first } \\
\text { premolars } \\
\text { to first } \\
\text { molars }\end{array}$ & $\begin{array}{l}\text { Optical } \\
\text { microscopy } \\
\text { coupled to } \\
\text { digital camera }\end{array}$ & $\begin{array}{l}\text { Correlation between } \\
\text { marginal misfit and } \\
\text { induced stress }\end{array}$ & 2009 \\
\hline Gomes et al. & $\begin{array}{l}4 \text { groups of } \\
3 \text {-elements fixed } \\
\text { prostheses over } \\
2 \text { abutments }\end{array}$ & 100 & $\begin{array}{l}\text { Mandibular } \\
\text { second } \\
\text { premolars } \\
\text { to second } \\
\text { molars }\end{array}$ & FEM & $\begin{array}{l}\text { Evaluation of the effect } \\
\text { of angular and vertical } \\
\text { misfit simulated on } \\
\text { screw-fixed prostheses }\end{array}$ & 2009 \\
\hline Castillo-Oyague et al. & $\begin{array}{l}30 \text { crowns }(10 \\
\text { 3-elements fixed } \\
\text { prostheses) }\end{array}$ & $\leq 150$ & - & SEM & $\begin{array}{l}\text { Evaluation of vertical misfit } \\
\text { and marginal infiltration } \\
\text { of laser-sintered and } \\
\text { vacuum-cast crown copings }\end{array}$ & 2012 \\
\hline Barros et al. & $\begin{array}{l}2 \text { bars with } \\
4 \text { abutments }\end{array}$ & Mean 108.6 & Mandibles & $\begin{array}{l}\text { Optical } \\
\text { microscopy }\end{array}$ & $\begin{array}{l}\text { Comparison of two different } \\
\text { technique bars, analyzing } \\
\text { the vertical misfit of each }\end{array}$ & 2013 \\
\hline Castillo-Oyague et al. & 60 crowns & $61.7-95.7$ & Premolars & $\begin{array}{l}\text { Digital } \\
\text { microscopy }\end{array}$ & $\begin{array}{l}\text { Evaluation of crown } \\
\text { copings obtained by laser } \\
\text { sintering and casting } \\
\text { techniques, luted with } \\
\text { glass ionomer, resin } \\
\text { cements, and acrylic/ } \\
\text { urethane-based agents }\end{array}$ & 2013 \\
\hline Eliopoulos et al. & 60 crowns & $<50-160$ & Premolars & $\begin{array}{l}\text { Optical } \\
\text { microscopy } \\
\text { and Tukey }\end{array}$ & $\begin{array}{l}\text { Comparison of marginal } \\
\text { and horizontal misfit of } \\
\text { frameworks for single } \\
\text { crowns built with/without } \\
\text { the use of prefabricated } \\
\text { plastic copings }\end{array}$ & 2013 \\
\hline Rodrigues et al. & & $106-116$ & $\begin{array}{l}\text { Premolars } \\
\text { to first } \\
\text { molars }\end{array}$ & $\begin{array}{l}\text { Optical } \\
\text { microscopy } \\
\text { and Tukey }\end{array}$ & $\begin{array}{l}\text { Evaluation of the precision } \\
\text { of four mold filling } \\
\text { techniques and verify an } \\
\text { accurate methodology to } \\
\text { evaluate these techniques }\end{array}$ & 2014 \\
\hline Bayramoglu et al. & 60 structures $(30)$ & $81-120$ & $\begin{array}{l}\text { Mandibular } \\
\text { first } \\
\text { premolars } \\
\text { to first } \\
\text { molars } \\
\text { and first } \\
\text { premolars } \\
\text { to second } \\
\text { molars }\end{array}$ & $\begin{array}{l}\text { Optical } \\
\text { microscopy }\end{array}$ & $\begin{array}{l}\text { Comparison of marginal } \\
\text { and internal misfit of } \\
3 \text { different restorative } \\
\text { materials and the effect of } \\
\text { veneering/pressing on the } \\
\text { material used for } 3 \text { - and } \\
\text { 4-element fixed prostheses }\end{array}$ & 2015 \\
\hline Ghanbarzadeh et al. & 10 crowns & $50-70$ & - & $\begin{array}{l}\text { Optical } \\
\text { microscopy }\end{array}$ & $\begin{array}{l}\text { Evaluation of the effect of } 3 \\
\text { different tightening torques } \\
\text { on marginal misfit of } \\
\text { 3-element cement-retained } \\
\text { fixed prostheses }\end{array}$ & 2015 \\
\hline
\end{tabular}

hexagon. This evinces a greater overload according to the discrepancy between abutment and prosthesis, even when the gap is below as $100 \mu \mathrm{m}$. However, the other articles examined in this study suggest that 
the magnitude of the marginal misfit is not a reliable indicator in the prognosis of the stresses generation, once the stress distribution is more related to other factors such as screw tightening. ${ }^{[29,33,36]}$

In most studies, the marginal discrepancy considered clinically usual was around $100 \mu \mathrm{m}$; however, Ghanbarzadeh et al..$^{[33]}$ and Siadat et al. ${ }^{[34]}$ considered lower values of 70 and $50 \mu \mathrm{m}$, respectively. The average of $100 \mu \mathrm{m}$ was only exceeded in three studies: Barros et al. ${ }^{[5]} 108 \mu \mathrm{m}$; Rodrigues et al., 2014: ${ }^{[36]} 110 \mu \mathrm{m}$; and Tramontino et al.: ${ }^{[29]} 118 \mu \mathrm{m}$. The study of Siadat et al. ${ }^{[34]}$ reported a clinically discrepancy at $50 \mu \mathrm{m}$ although the laboratory tests have revealed slightly higher values. Three studies revealed results that are suitable for this standard, obtaining a misfit mean values of $45,^{[33]} 45.1,^{[35]}$ and $50 \mu \mathrm{m} \cdot{ }^{[28]}$

It was not possible to notice evolution in the reduction of the abutment misfit over the years, nor statistically significant values among materials or steps since the misfit is considered tolerable by clinicians. It is known that there is a biological tolerance for marginal discrepancy, but the maximum value of this misfit still should be reviewed, once it is based on empirical studies and there is a lack of standard protocols among the studies.

\section{CONCLUSION}

The vertical prosthetic-abutment misfit depends on several steps during prosthetic procedures, which includes the materials and technical procedures. Lower values of prosthetic-abutment misfit are obtained when precious metal or titanium alloys are used. Although a vertical misfit mean value of $100 \mu \mathrm{m}$ has been considered clinically usual, most of the previous studies included in this revision showed lower mean values.

\section{Financial support and sponsorship}

Nil.

\section{Conflicts of interest}

There are no conflicts of interest.

\section{REFERENCES}

1. Cruz HJ, Souza JC, Henriques M, Rocha LA. Tribocorrosion and bio-tribocorrosion in the oral environment: The case of dental implants. In: Paulo Davim J, editor. Biomedical Tribology. New York, USA: Nova Science Publishers, Inc.; 2011. p. 1-33.

2. Macedo JP, Pereira J, Vahey BR, Henriques B, Benfatti CA, Magini RS, et al. Morse taper dental implants and platform switching: The new paradigm in oral implantology. Eur J Dent 2016;10:148-54.

3. Dias EC, Bisognin ED, Harari ND, Machado SJ, da Silva CP, Soares GD, et al. Evaluation of implant-abutment microgap and bacterial leakage in five external-hex implant systems: An in vitro study. Int J Oral Maxillofac Implants 2012;27:346-51.

4. Chechinato F, Rigo L, Federizzi L, Schuh C, Spazzin AO. Vertical misfit between prefabricated or casting prosthetic abutments and implant. Rev Odontol UNESP 2012;41:198-202.

5. Barros VM, Fontoura DC, Discacciati JA, Vasconcellos WA, Oliveira CS Jr., Vaz RR. Comparison of vertical misfit between cast and CNC-milled frameworks for implant-supported prostheses. Implant News 2013;10:21-7.

6. Pereira J, Morsch CS, Henriques B, Nascimento RM, Benfatti CA, Silva FS, et al. Removal torque and biofilm accumulation at two dental implant-abutment joints after fatigue. Int J Oral Maxillofac Implants 2016;31:813-9.

7. Prado AM, Pereira J, Henriques B, Benfatti CA, Magini RS, López-López J, et al. Biofilm affecting the mechanical integrity of implant-abutment joints. Int J Prosthodont 2016;29:381-3.

8. Duarte AR, Neto JP, Souza JC, Bonachela WC. Detorque evaluation of dental abutment screws after immersion in a fluoridated artificial saliva solution. J Prosthodont 2013;22:275-81.

9. Barbosa GA, Bernardes SR, das Neves FD, Fernandes Neto AJ, de Mattos Mda G, Ribeiro RF, et al. Relation between implant/abutment vertical misfit and torque loss of abutment screws. Braz Dent J 2008;19:358-63.

10. Barbosa GA, das Neves FD, de Mattos Mda G, Rodrigues RC, Ribeiro RF. Implant/abutment vertical misfit of one-piece cast frameworks made with different materials. Braz Dent J 2010;21:515-9.

11. Hamilton A, Judge RB, Palamara JE, Evans C. Evaluation of the fit of CAD/CAM abutments. Int J Prosthodont 2013;26:370-80.

12. Baldassarri M, Hjerppe J, Romeo D, Fickl S, Thompson VP, Stappert CF, et al. Marginal accuracy of three implant-ceramic abutment configurations. Int J Oral Maxillofac Implants 2012;27:537-43.

13. Souza JC, Henriques M, Oliveira R, Teughels W, Celis JP, Rocha LA, et al. Biofilms inducing ultra-low friction on titanium. J Dent Res 2010;89:1470-5.

14. Souza JC, Henriques M, Oliveira R, Teughels W, Celis JP, Rocha LA, et al. Do oral biofilms influence the wear and corrosion behavior of titanium? Biofouling 2010;26:471-8.

15. Pellizzer EP, Verri FR, Falcón-Antenucci RM, Júnior JF, de Carvalho PS, de Moraes SL, et al. Stress analysis in platform-switching implants: A 3-dimensional finite element study. J Oral Implantol 2012;38:587-94.

16. Alves da Cunha Tde M, Correia de Araújo RP, Barbosa da Rocha PV, Pazos Amoedo RM. Comparison of fit accuracy between procera custom abutments and three implant systems. Clin Implant Dent Relat Res 2012;14:772-7.

17. Fernández M, Delgado L, Molmeneu M, García D, Rodríguez D. Analysis of the misfit of dental implant-supported prostheses made with three manufacturing processes. J Prosthet Dent 2014;111:116-23.

18. Solá-Ruíz MF, Selva-Otaolaurruchi E, Senent-Vicente G, González-de-Cossio I, Amigó-Borrás V. Accuracy combining different brands of implants and abutments. Med Oral Patol Oral Cir Bucal 2013;18:e332-6.

19. Pompa CC, Ribeiro ED, Sousa SB. Peri-implantitis: Diagnosis and therapy. Innov Implantol J Biomater Esthet 2009;4:52-7.

20. Gomes EA. Evaluation of vertical and angular misfit in implantsupported fixed prostheses using 3D-FEA. $121 \mathrm{f}$. Thesis (Doctorate) - Dentistry Graduate, Unesp, Araçatuba; 2009.

21. Cicciù M, Bramanti E, Cecchetti F, Scappaticci L, Guglielmino E, Risitano G, et al. FEM and von mises analyses of different dental implant shapes for masticatory loading distribution. Oral Implantol (Rome) 2014;7:1-10.

22. Bramanti E, Cervino G, Lauritano F, Fiorillo L, D'Amico C, Sambataro $S$, et al. FEM and von mises analysis on prosthetic crowns structural elements: Evaluation of different applied materials. ScientificWorldJournal 2017;2017:1029574.

23. Macedo JP, Pereira J, Faria J, Pereira CA, Alves JL, Henriques B, et al. Finite element analysis of stress extent at peri-implant bone surrounding external hexagon or morse taper implants. J Mech Behav Biomed Mater 2017;71:441-7.

24. Cicciu M, Bramanti E, Matacena G, Guglielmino E, Risitano G. FEM evaluation of cemented-retained versus screw-retained dental implant single-tooth crown prosthesis. Int J Clin Exp Med 2014;7:817-25.

25. Cicciù M, Risitano G, Maiorana C, Franceschini G. Parametric analysis of the strength in the "toronto" osseous-prosthesis system. Minerva 
Stomatol 2009;58:9-23.

26. Lauritano F, Runci M, Cervino G, Fiorillo L, Bramanti E, Cicciù M, et al. Three-dimensional evaluation of different prosthesis retention systems using finite element analysis and the von mises stress test. Minerva Stomatol 2016;65:353-67.

27. PRISMA Checklist; 2009. Available from: http://www.prismastatement.org/documents/PRISMA 2009checklist.pdf. [Last accessed on 2016 May 03]

28. Eliopoulos D, Torsello F, Cordaro L. Marginal discrepancies of Ni/Cr crowns for a soft tissue-level, trans-mucosal implant system. Clin Oral Implants Res 2013;24 Suppl A100:82-7.

29. Tramontino VS, Daroz LG, Luthi LF, Mesquita MF, Nóbilo MA, Henriques GE. Correlation between marginal misfit and strains around implants. Rev Fac Odontol UPF 2009;14:47-50.

30. Castillo-de-Oyagüe R, Sánchez-Turrión A, López-Lozano JF, Albaladejo A, Torres-Lagares D, Montero J, et al. Vertical misfit of laser-sintered and vacuum-cast implant-supported crown copings luted with definitive and temporary luting agents. Med Oral Patol Oral Cir Bucal 2012;17:e610-7.

31. Castillo-Oyagüe R, Lynch CD, Turrión AS, López-Lozano JF, Torres-Lagares D, Suárez-García MJ, et al. Misfit and microleakage of implant-supported crown copings obtained by laser sintering and casting techniques, luted with glass-ionomer, resin cements and acrylic/urethane-based agents. J Dent 2013;41:90-6.

32. Bayramoğlu E, Özkan YK, Yildiz C. Comparison of marginal and internal fit of press-on-metal and conventional ceramic systems for three- and four-unit implant-supported partial fixed dental prostheses: An in vitro study. J Prosthet Dent 2015;114:52-8.

33. Ghanbarzadeh J, Dashti H, Karamad R, Alikhasi M, Nakhaei M. Effect of tightening torque on the marginal adaptation of cement-retained implant-supported fixed dental prostheses. Dent Res J (Isfahan) 2015;12:359-64.

34. Siadat H, Alikhasi M, Mirfazaelian A, Zade MM. Scanning electron microscope evaluation of vertical and horizontal discrepancy in cast copings for single-tooth implant-supported prostheses. Implant Dent 2008;17:299-308.

35. Oyagüe RC, Turrión AS, Toledano M, Monticelli F, Osorio R. In vitro vertical misfit evaluation of cast frameworks for cement-retained implant-supported partial prostheses. J Dent 2009;37:52-8.

36. Rodrigues MA, Luthi LF, Takahashi JM, Nobilo MA, Henriques GE. Strain gauges's analysis on implant-retained prosthesis' cast accuracy. Indian J Dent Res 2014;25:635-40. 